Article

\title{
On the Relationship between Documentary Films and Magic Lanterns in 1950s Japan
}

\author{
Koji Toba \\ Faculty of Letters, Arts and Sciences, Waseda University, Tokyo 162-8644, Japan; toba@y.waseda.jp
}

Received: 22 March 2019; Accepted: 10 May 2019; Published: 17 May 2019

check for
updates

\begin{abstract}
In this paper, I explore three cases from postwar Japanese media history where a single topic inspired the production of both documentary films and magic lanterns. The first example documents the creation of Maruki and Akamatsu's famed painting Pictures of the Atomic Bomb. A documentary and two magic lantern productions explore this topic through different stylistic and aesthetic approaches. The second example is School of Echoes, a film and magic lantern about children's education in rural Japan. The documentary film blurs distinctions between the narrative film and documentary film genres by utilizing paid actors and a prewritten script. By contrast, the original subjects of the documentary film appear as themselves in the magic lantern film. Finally, the documentary film Tsukinowa Tomb depicts an archeological excavation at the site named in the title. Unlike the monochrome documentary film, the magic lantern version was made on color film. Aesthetic and material histories of other magic lanterns include carefully hand-painted monochrome films. Monochrome documentary films in 1950s Japan tended to emphasize narrative and political ideology, while magic lantern films projected color images in the vein of realism. Through these examples of media history, we can begin to understand the entangled histories of documentary film and magic lanterns in 1950s Japan.
\end{abstract}

Keywords: magic lantern; documentary film; popular history movement

\section{Introduction}

Documentary films and magic lanterns share intertwined production and viewing histories in wartime and postwar Japan. In 1930s and early 1940s Japan, documentary film and magic lanterns both faced strict government regulation regarding production and distribution. This complex and intertwined relationship continued under the Allied Occupation's regulation of cultural production. During the postwar period specifically, documentary film and magic lantern productions often shared narrow historical or social topics, as well as similar production and release timelines. These media simultaneously addressed similar social realities, albeit from varying creative and ideological positions. In this paper, I will introduce three cases from 1950s Japan in which magic lanterns and films or other media had direct, yet unique relationships. Unlike their wartime media counterparts, the magic lanterns and documentary films produced in the 1950s could be considered the fruits of Japan's so-called "Postwar Democracy". As we will find in the examples below, ordinary people gathered to participate in the production of both media forms. Thus, this study extends beyond the facts within the frame, arguing that the fundamental historical basis for postwar magic lanterns or documentary films necessarily includes the often-entangled processes by which these media were produced. In this sense, they should be considered additional forms of what Justin Jesty has described as "engagement", "a promise, a commitment, but one that is not coerced" (Jesty 2018, p. 36). 


\section{Material and Cultural History of Magic Lanterns in Japan from Wartime to Postwar}

Magic lanterns, also known by the Latin name laterna magica, project images to a screen by illuminating transparent glass or film. Today, magic lanterns are known as an early form of projected media that flourished in the 19th century for the purposes of education and entertainment. In education, the magic lantern's direct successor was the slide projector, which itself has been replaced by PowerPoint today. The rise of cinema in the early 20th century gradually displaced magic lanterns for entertainment in the West. Magic lanterns as a media of entertainment follow a similar historical trajectory in Japan as well. In the Japanese case, however, the magic lantern (gentō in Japanese) survived even after cinema's emergence as the dominant media of entertainment. This is especially true for magic lanterns as the media of education. Beginning in the early 1930s, the Japanese Ministry of Education introduced magic lantern media to schools as an inexpensive way to show visual materials to children. In 1941, the Ministry redefined and regulated a new form of magic lantern, one which projected still images of $35 \mathrm{~mm}$ movie films, rather than glass plates. The Ministry promoted this new system of magic lantern media and scripts nationally alongside wartime propaganda films (Washitani 2013, pp. 81-91). From the earliest stages, film and magic lanterns in Japan possess an entangled media history, rather than a relationship of replacement or obsolescence.

After the war, the Allied Occupation's Civil Information and Education (CIE) section introduced "audio-visual education" to Japan. They lent 1300 Natco $16 \mathrm{~mm}$ talkie projectors and 650 Beseler magic lanterns to Japan's Ministry of Education. CIE and the Ministry of Education distributed educational films across Japan. Half of the films were imported from the US and half were produced in Japan (Yoshihara 2011, pp. 92-96). In 1946, only 5.8\% of Japanese cities, towns, and villages had movie theaters (Harada 2012, p. 265). People in Japan who had never seen a movie before welcomed these Occupation and Ministry-distributed films. On average, Japanese people had watched more than ten CIE movies by July 1951 (Tsuchiya 2009, p. 131). CIE also provided $35 \mathrm{~mm}$ magic lantern films to the public, though the physical media differed from Japanese magic lanterns. CIE distributed vertically oriented magic lantern film, like the $35 \mathrm{~mm}$ film used in movies. The Japanese projector was oriented horizontally, similar to $35 \mathrm{~mm}$ still cameras. Japanese magic lantern films were therefore easily produced using ordinary film cameras. Although the CIE magic lantern as a physical media format failed to take hold, the tradition of magic lanterns as projected media continued from Japan's wartime period.

One reason magic lanterns survived in Postwar Japan was their utility in disseminating trailers of independently produced films. Low-budget film productions could affordably and rapidly produce magic lantern film trailers that could be screened in rural villages, even those without movie theaters. Independent film-makers produced and distributed magic lanterns for use as mobile film trailers. More than forty examples of magic lantern trailers produced by independent film-makers are extant today. ${ }^{1}$ In addition to entertainment media producers, activists frequently made use of magic lanterns to promote social or political movements. One such example concerns the 63-day strike for wage increases undertaken by the Japan Coalminers' Union from October to December of 1953. The Coalminers' Union produced the magic lantern film How We Fight: The 63-Day Struggle. More than one-thousand copies of this film were then reproduced by the magic lantern film distributor Nihon Gentō Bunkasha. When subsequently shown throughout Japan, the film played a significant role in promoting the strike. With How We Fight's success, many labor unions began producing magic lantern films as a propaganda tool (Kamiya and Washitani 2012, pp. 72-74).

Like their magic lantern counterparts, documentary films share similarly complex histories of wartime and postwar government control. Documentaries, called "culture films" (bunka eiga) from the

1 For example, Kōbe Eiga Shiryōkan holds physical copies of more than forty trailers. These include Yamamoto Satsuo's Zone of Emptiness (Shinkū Chitai, 1952), Kamei Fumio's Woman Walking Alone on the Earth (Onna Hitori Daichi o Yuku, 1953), and Imai Tadashi's Here is a Fountain (Kokoni Izumi Ari, 1955). 
German film genre "Kulturfilm", were also used for media propaganda in wartime Japan. The Japanese government promulgated a movie law (eiga hō) modeled on Italian and German policies, which came into effect in 1939. The law made it the duty of every movie theater in Japan to show at least one culture film and one news film for each narrative film screened (Okudaira 1986, pp. 49-253). This law brought on a golden age of Japanese documentary films as budgets available to documentary filmmakers ballooned in order to meet demand. Production companies producing documentary films during wartime continued on during the postwar period, supported by the Ministry of Education for educational purposes and by private companies for public relations purposes.

Fruitful comparisons between documentary films and magic lanterns exist beyond their relationship with government control. They also demonstrate the complexities of historicizing aesthetic trends in postwar media, particularly the history of color projected media and conceptions of realism in relation to technological advancement. Whereas the majority of documentary films were produced using monochrome film, magic lanterns were generally projected using color slides or frames. Paradoxically, viewers of magic lantern productions found reality expressed by the color and details of the film, despite their lack of movement. Documentary films, on the other hand, tended to embrace stylistic elements found in narrative films while conveying leftwing ideology. As was the case with production history, adding color embellishments to monochrome film or slides for magic lanterns-or using expensive color film from the start-began during wartime. The Asahi Shimbun reported on the military's use of "natural color (ten'nen-shoku)" magic lantern films from 1943 to $1944 .^{2}$ As it was too expensive to use color film in the production of documentaries during the war, magic lantern films played a supplementary role to the aesthetic tendencies of monochrome documentary films.

\section{Efforts to Record the Tragedy of the Atomic Bomb: Pika-Don (1952) and Pictures of the Atomic Bomb (1953)}

The first examples I would like to discuss are the documentary film and two magic lantern films produced about Pictures of the Atomic Bomb (Genbaku no Zu), popularly known as "The Hiroshima Panels". The panels themselves were produced between 1950 and 1982 by artists Maruki Iri and Akamatsu Toshiko. Together, they painted a series of fifteen pictures on large traditional Japanese panels that depict the tragic details of the atomic bombing in Hiroshima. The titles are: 1. Ghosts, 2. Fires, 3. Water, 4. Rainbow, 5. Boys and Girls, 6. Atomic Desert, 7. Bamboo Thicket, 8. Rescue, 9. Yaizu (the home port of the fishing boat Lucky Dragon 5 which was exposed to US hydrogen bomb testing in the Pacific), 10. Petition, 11. Mother and Child, 12. Floating Lanterns, 13. Death of American Prisoners of War, 14. Crows, and 15. Nagasaki. They established the Maruki Gallery for The Hiroshima Panels in 1967 to display the panels to the public. ${ }^{3}$

When the artist couple was painting the sixth panel in 1952, director Aoyama Michiharu visited their studio to capture their work in a documentary film. Aoyama and co-director Imai Tadashi planned to produce a short film to introduce the panels and record the terrible damage caused by the bomb. Aoyama and Imai's Pictures of the Atomic Bomb was released in 1953 with a running time of seventeen minutes. The film depicted Maruki and Akamatsu painting the panel, close examinations of the panels themselves, and the reception of the panels in nationwide exhibitions held in 1952. The filmmakers superimposed footage of other documentary films and pictures of Hiroshima to provide context for the painted panels. Their film was not only widely shown in Japan, but it was also screened to audiences

2 Articles include: New Weapon of Propaganda for East Asia (Tōa e "Senden" no Shin-heiki), p. 2, 7 June 1943; Magic Lantern Exhibitions of War Paintings (Sensōga no Gentōten), p. 2, 14 February 1944; All 100 Million Citizens are Marching to Destroy the Enemy (Metteki e 1 oku Sōshingun), p. 3, 1 March 1944; From the Oath of Destroying the Enemy to Increasing Production (Metteki no Chikai o Zōsan e), p. 1, 10 March 1944; Natural Colored Magic Lantern Exhibition (Ten'nen-shoku Gentō Bijutsuten), 1 November 1944. All anonymous reports.

3 Some of the pictures were shown in Washington D.C., Boston, and Brooklyn in 2016. The Brooklyn exhibition was selected to the "Best of 2015: Our Top 10 Brooklyn Art Shows" by the art magazine Hyperallergic (Hyperallergic 2015). 
in Paris, Antwerp, and Brussels, where it was paired with Shindō Kaneto's The Children of Hiroshima (Genbaku no Ko) (Okamura 2015, pp. 181-82).

Establishing a reception history of this short documentary is somewhat difficult, but contemporaneous print media included reviews of the film. In 1952, an anonymous critic reviewed the film in the magazine Soveto Eiga. The reviewer's anonymity is problematic for researchers, but was typical of the time. Japanese magazines and newspapers often publish media reviews without identifying the author. The reviewer wrote:

In the Soviet Union, introducing paintings through film began with the collected paintings of Repin and Surikov. There are some examples in France, also. But this work (Pictures of the Atomic Bomb) is successful because it captures not only a number of the paintings, but also the boundless growth of the artists as they evolve through their interactions with the masses. (Anonymous 1952, p. 84)

Maruki Iri and Akamatsu Toshiko also published a small illustrated book called Pika-Don in 1950. ${ }^{4}$ "Pika" is a mimetic word that suggests a bright flash, while "Don" is an onomatopoeia of an explosion. This combination was widely used by the victims in Hiroshima to describe the atomic bomb, which was characterized by a sudden flash followed by the sound of a massive blast. Pika-Don was published in the style of a palm-sized Chinese picture book called a liánhuánhuà. Each page had a large illustration and a brief textual description. The story begins with a peaceful morning scene in the town of Mitaki northwest of Hiroshima City on August 6. When the narrator states "It was 8 o'clock. There was a light that flashed like pika", everything takes a turn for the worse. The protagonist, a woman based on Maruki's mother, is surprised that she can see the Ujina port, southeast of the city, because the buildings in between have vanished. Each page depicts various scenes of atom-bombed areas. The most famous page illustrates black, burnt trees with the description, "Nobody can tell the story of ground zero". The latter half of the book depicts the symptoms of illnesses caused by atomic-bomb radiation. The narrator describes the protagonist's actions after her husband dies; she starts to paint flowers and doves. The story ends with an illustration of two doves she has drawn. On the final page, the narrator states that after the Potsdam Declaration, the government tried to negotiate with the United Nations to save the position of the emperor. "If the people had known that this terrible thing would be dropped on August 6, all the people of Japan should have screamed out, 'Please stop the war!'”

The production company Seieisha produced the magic lantern version of Pika-Don in 1952 based on this illustrated book. The story and illustrations are essentially the same as the book, but the illustrations on $35 \mathrm{~mm}$ monochrome film are intricately hand-colored. Additionally, a separate production company, Kinuta Yokoshine, made a second magic lantern film in 1953. This version was named Pictures of the Atomic Bomb. Sculptor Hongō Shin was asked to create the order of pictures to be presented in this magic lantern and painter Uchida Iwao wrote the description for each image. Both were famous communist artists. Unlike Aoyama's documentary film, this magic lantern introduced the panel paintings in such detail that it could be used as a substitution for the actual exhibition of the panels. Uchida seemed to have recognized the magic lantern's potential as a proxy exhibit. His script contains the following directions: "When you project this film, pull it slowly as if you were walking in front of the picture in an exhibition" (Okamura 2015, p. 185).

In the case of Pictures of the Atomic Bomb, the documentary film and the magic lantern films played supplementary roles for each other. While the documentary film explained Maruki and Akamatsu's painting process and the effects of the bomb itself, the second magic lantern film showed the audience minute details of the paintings. The first magic lantern film, Pika-Don, depicted an additional story of the bomb using simple, yet beautifully colored pictures. Together, these media acted as an accounting of both Maruki and Akamatsu's creative process, as well as a historical record of the aftereffects of

4 Maruki and Akamatsu published a reprint of this book with English translations in 1976. Maruki, Iri \& Maruki, Toshi. Ed. by Suzuki, Haruhisa. Trans. by Matsumura, Ken'ichi. Pika-Don. Tokyo: Roba no Mimi sha. 1976. 
atomic bombings. Audiences that viewed the film and both magic lanterns came to understand the tragedy which occurred under the mushroom cloud.

\section{Voices from Students in the Deep Mountains: School of Echoes (1951)}

The second example deals with students of a junior high school in Yamagata prefecture, located in Japan's rural northeast. In 1951, a collection of school compositions by these students was published in a volume called School of Echoes (Yamabiko Gakkō). ${ }^{5}$ Muchaku Seikyō, a young teacher in Yamagata, encouraged his students to observe and write about their everyday lives for their writing assignments. The students wrote about problems like rural poverty and hardship. School of Echoes became a landmark text in democratic cultural production. The innocent voices of students in a poor, isolated village deep in the mountains roused children and adults to participate in independent publishing projects of their own. The volume was received as an ideal example of postwar democratic education put into practice (Sano [1992] 2005, p. 12). Teachers and students in other schools began following this text's example in their own classrooms. Workers in factories also began to chronicle their everyday lives in self-organized literary circles. They published small magazines by mimeograph, whereupon the publications were exchanged with other circles (Toba 2016, pp. 155-74).

At the pinnacle of the "echoes" (yamabiko) boom, director Imai Tadashi visited the original Yamagata village to shoot a narrative film School of Echoes. Imai brought Kimura Isao and other established actors with him from Tokyo, shooting scenes on location that reproduced episodes described in the book. Kimura acted in the role of the teacher Muchaku, playing the character as a young, passionate educator. Before the premiere screening, Imai described the film as follows:

This film is not a so-called narrative film. Rather, it could be called a documentary film. To date, films dealing with schools have typically depicted the arrival of a new teacher, pressures from PTA (Parent-Teacher Association) bosses or feudal-minded principals, and love affairs between male teachers and a female student or teacher. After a series of conflicts, these movies tend to resolve all the problems peacefully. I tried, however, to portray the reality of the hard lives in Japanese villages, focusing on the teacher Muchaku and the children. The film's script, direction, and filming are dedicated to this aim. I hope that audiences contemplate this decision while watching the film, as well as appreciate the cooperation we received from the local people in Yamagata, the teacher's union, and the labor union. (Kanzaki 1952, pp. 43-44)

The film's plot emphasizes efforts by Muchaku and the students to relieve their classmates of hardship. When eight students could not afford the expenses of the school trip prior to graduation, their classmates worked in the mountains to pay the cost for them. After a student's mother dies of heart disease, the classmates worked his family's tobacco field so that he could graduate. Muchaku then encourages his students to chronicle poverty as they experienced it, publishing the first issue of the class magazine by mimeograph.

Imai's School of Echoes was based on real episodes in the everyday life of the village and shot on location. In this sense, it is unlike a narrative film produced in a studio. And yet, a contemporary audience would likely call the typical production process of documentary films of that time staged or fake. Unlike the contemporary conception of documentary filmmaking, in 1950s Japan a script writer or director wrote scenes for the documentary beforehand, then asked the crew to shoot the scenes as written. This is not to argue that documentary films of the time were produced without a concept of realism in mind. Rather, a documentary film's claim to realism was judged by different criteria. When director Kyōgoku Takahide's 1955 documentary film A Record of a Mother (Hitori no

5 An English translation of this book was published three years later. Muchaku, Seikyō. Trans. by Caulfield, Genevieve \& Kimura, Michiko. Echoes from a Mountain School. Tokyo: Kenkyūsha. 1954. The Government of New Zealand reprinted the English translation in 1965. 
Haha no Kiroku) caused controversy over whether or not it could be called a documentary, the point of contention was not the production history of the film's scenario. The film was controversial because Kyōgoku invented a fictitious family for the film. He did not shoot the real family upon which the documentary was based, rather he selected interesting individuals from different families in the village and called them a family in the film. When Hani Susumu made Children in the Classroom (Kyōshitsu no Kodomotachi), also in 1955, the audience was surprised by realistic portrayals of children's everyday actions. Children took pencils in their mouths like cigarettes, or patted the head of a friend from behind, generally acting as if there were no adults or supervisors watching over them. These actions and movements were unconventional at the time. Before writing the script, Hani had studied the arbitrary behaviors of children by shooting large amounts of film. Prior to this film's release, children in educational films were well-behaved and nervous about being filmed. The vast amount of filming in preparation for Children in the Classroom was only possible through the sponsorship of the Ministry of Education, which was at that time trying to establish a model of democratic education. Without this budget, Hani would have been forced to decide the contents of the scenes containing children before filming began, likely reproducing the acting tropes already established in the genre (Toba 2010, pp. 81-88).

When the documentary film based on School of Echoes went into production, Muchaku was eager to act as himself in the film, but Imai refused to allow his participation. The entire cast and crew went to Yamamoto village in Yamagata from Tokyo. While the film's production history suggests a significant degree of fictionalization, this does not preclude School of Echoes from being classified as a documentary film based on the conventions of genre categorization at that time. The episodes in the film were based on documented experiences of the actual students. Scenes from the film recreated these genuine events on location. In order to place the film in its historical context, we might compare it to $A$ Record of a Mother, discussed above. It was generally accepted at the time that $A$ Record of a Mother could be called a documentary film, despite an even greater degree of fictionalization. When considering the historical trends in documentary filmmaking in 1950s Japan, it seems logical that School of Echoes would be eligible for the same categorization.

Muchaku's dream of acting as himself on film came true when the magic lantern version of School of Echoes was produced by the Rural Culture Association of Japan. In the magic lantern film, Muchaku and the students appear as themselves. Like the movie, the story is based on episodes from the book. Given Muchaku and the children's inexperience with dramatic acting, it does not seem farfetched to argue that, had they in fact been cast as themselves in Imai's film production, the quality of acting may have been miserable. But for the magic lantern film, the amateur actors needed not speak or move for the camera. Without the need for extensive direction, the magic lantern successfully captures that which might be called genuine expression on the amateur actor's faces. What is more, the magic lantern version of School of Echoes reproduces beautiful landscape shots which convey the realities of a deep mountain village. The magic lantern also depicts the students' classroom in detail, as well as the actual home of a student. Shot on monochrome film, each frame of the magic lantern was carefully hand-painted in an effort to express to the audience the real environment where the students lived. While the movie depicted some of the troubles that students faced, the magic lantern film recorded the real faces and scenes of the village. In this sense, these two films and formats hold different values as documentary media. Taken together in their historical context, the original text, the documentary film adaptation, and the magic lantern demonstrate the complex interrelations of documentary and narrative, reality and fiction, monochrome and color-often in ways that complicate the seemingly dichotomous relationship between these characteristics.

\section{Unearthing History: The Tsukinowa Tomb (1954)}

The third example, a documentary and magic lantern about local archeologists uncovering ancient tombs, lays bare the entangled nature of history education, government control, and media history during both wartime and postwar Japan. From the Meiji Restoration in 1868 to the surrender in 1945, 
history education in Japan had a close relationship with the Emperor system. Japanese history textbooks traced the beginning of historical time from the mythical first emperor Jinmu, whose reign was supposed to have lasted from $660 \mathrm{BC}$ to $585 \mathrm{BC}$. Students in elementary school were required to memorize the names of Japan's 124 Emperors, from Jinmu to the wartime Emperor Showa. The historical legitimacy of the Emperor was the core value in education, as well as in politics. The Emperor was fashioned a living god. This is why it was so shocking for Japanese people to see a picture of General McArthur and the Emperor standing side-by-side on the cover of newspapers on 29 September 1945. The Emperor declared his own humanity on 1 January 1946, publicly denying the concept of his being a living god.

Education changed drastically during the occupation era. GHQ (General Headquarters) banned the education of certain subjects in elementary schools, for example "Morals" (Shūshin), "National History" (Kokushi), and "Geography" (Chiri). Instead, they introduced the "Social Studies" (Shakaika) curriculum to replace these classes with the intention that students would learn the concept of democracy. One of the accomplishments of the new social studies curriculum was the book School of Echoes, discussed above. Muchaku Seikyō encouraged students to write their compositions not in the students' Japanese language class, but during the new social studies course. Muchaku recommended that students observe their home, school, and village, and to describe the problems they found. In higher education, the teaching of history courses could not be abolished outright, so Occupation authorities instituted specific curricular changes. The names of early Emperors-those thought to be mythical rather than historical rulers-were purged from textbooks. These new history textbooks now opened with archaeology lessons, rather than historical legitimizations of the Emperor's divine right to rule.

Occupation-era changes to history education, particularly the emphasis on archeology as the appropriate methodology of prehistorical investigation, inspired democratically organized historical societies. One example of the results of these studies is the extensive exploration of the Toro Remains (Toro Iseki), an archeological site in Shizuoka prefecture. The site consisted of a 1st century village, including many houses and large rice paddies. The ruins were discovered in 1943 when the government planned to build a munitions factory at the site. After a very limited excavational investigation, the government continued with construction and archeologists lost access to the site. In 1947, however, multiple universities formed an excavation team to explore the ruins. Many students from local high schools and junior high schools volunteered to help scholars and students of the university team. As mass media reported on the excavation nationwide, Toro became a symbol of novel archaeological and historical trends in newly democratic Japan.

In the 1950s, history was problematized in a different way by leftist scholars. Ishimoda Shō published The Discovery of History and The People (Rekishi to Minzoku no Hakken) in 1952. In this book, Ishimoda encouraged people to write their own histories. His slogan became: "Let us write the histories of our villages, of our factories". This historical movement came to be called "The Popular History Movement (Kokuminteki Rekishigaku Undō)", and took Ishimoda's book as the movement's core text.

The Tsukinowa Tomb (Tsukinowa Kofun), the tomb of a local political leader from the 5th century, sat at the top of a small mountain in Okayama prefecture. It also sat at the crossroads of these two historical trajectories: the resurgence of archeology under Occupation education reform and the development of local, democratic historical investigations. It was common knowledge among local residents that the small mountain in Yūka village was an ancient tomb. Before media coverage of the archeological excavations at the Toro Remains reached the town, however, residents of Yūka had never considered excavating the tomb. At the peak of the Popular History Movement, local residents determined that they could carry out excavation work by themselves.

In 1952, they organized a local history circle. They invited Professor Kondo Yoshirō of Okayama University to join their research of local history. The circle grew rapidly and soon formed plans to excavate the Tsukinowa Tomb in August of 1953, the off-season for farmers in the village who were participating in the history circle. Given that the timing of this project fell in the midst of summer 
vacation, students of all ages, from elementary schools to universities, joined the project. As concrete planning moved forward, the intersection of archeology and democratic historical societies converged with the climate of democratically produced media. As such, the Yūka history circle planned to produce a documentary film of the Tsukinowa Tomb excavation. Circle members visited Tokyo to recruit film production specialists to the project. Directors Arai Hideo and Sugiyama Masami, scriptwriter Yoshimi Tai, and film production staff agreed to produce the film. The filmmakers first visited the village in September of 1953. The successful collaboration between local historians and established filmmakers exceeded the original project timeline, with excavation and filming continuing until November of the same year (Kokuni 2007, pp. 100-24).

The documentary film Tsukinowa Tomb was released in 1954. It depicts the process of excavation during the daytime and the local history circle's courses in the evening. The film's narrator recites poetry penned by junior high school students participating in the project over shots of students working together on the excavation. One poem reads as follows:

“Ancient Tomb" by Toyofuku Emiko, 1st grade of Fukumoto Junior High School.

Ancient tomb on Mount Oji/Tearing the earth, little by little/The sweat stings when it gets in my eyes/My back hurts/Sunlight pierces through my gym clothes/Clay figures roll out from the soil/No matter how many times I dig there/Who buried so many?/Digging tree roots with scissors/Crouching to work my bamboo chisel/I study history with all my body/It must have been so hard/To bring these objects to this high place!

When the excavation discovers a smaller tomb at the bottom of the mountain, the film suggests a theory that structures of discrimination and class difference were already extant during the ancient era of the ruins. The narrator takes the opportunity to criticize the existence of discrimination then and now. The film also highlights the onsite visit of Prince Mikasa, the youngest brother of Emperor Hirohito. As an archaeologist himself, he demonstrated an interest in the excavation. But depicting his visit as a special event is one contradiction present in this film. The film criticizes discrimination on the one hand, while on the other hand praising the visit of a person possessing a social status similar to those buried at the site. The film relies on Prince Mikasa's comments regarding the importance of the project to justify the excavation.

The Ministry of Education's Council for Educational Films recommended designating Tsukinowa Tomb a "Ministry recommended film", but the Minister rejected the motion. This was due to the leftist nature of the film. Prince Mikasa's personal donations and recommendation did not sway the Minister's attitude toward the film (Anonymous 1954, p. 7).

The magic lantern film of Tsukinowa Tomb was released on color film in 1954 as a joint production between a local cultural circle and the Okayama prefectural teachers' union. The magic lantern version demonstrates clear connections to the documentary film-it cites the same poem by Toyofuku and depicts Prince Mikasa's visit to the site-but the material presentation varies. In the clearest sense, the magic lantern's use of color film presents an aesthetic difference from the monochrome documentary film. The vivid color of the sky, grass, and earth gives the audience tactile images of the excavation site. Furthermore, the closing remarks of the magic lantern script are more positive than the documentary film:

The learning that occurred in Tsukinowa was founded on the members' cooperation. This in turn lit the hearts of the participants who were thinking seriously about how all people might find happiness. Children, teachers, scholars and villagers of Tsukinowa came to think: "It is up to us to make our new history". "Our power creates a peaceful society". Let us promote their works in our everyday lives!

In this closing statement, the democratic spirit of The Popular History Movement resonates with the viewers of the magic lantern version of Tsukinowa Tomb. History need not remain a distant endeavor, detached from the everyday lives of the people. Rather, each participant in the excavation of the Tomb 
approached the project with the expectation that they might learn a lesson from their own history. In the case of the magic lantern version of the film, the narrator suggests that participation in the intersecting trends in democratic history might bring improvement to one's own life, creating possibilities for new and better histories of tomorrow. The documentary film of Tsukinowa Tomb criticized social injustices of the ancient era. The magic lantern film of the same title, however, projected in vibrant natural color, attempted to capture and illuminate a bright future.

\section{Conclusions}

In Japan, magic lanterns not only survived until the 1950s, they also played a major role in postwar media and cultural movements. Due to lower production costs, magic lantern film production was widely used across Japan to deal directly with topics often covered by contemporaneous documentary films. As in the examples explored above, magic lanterns depicted artwork, highlighted social movements, and recorded local events. This understudied postwar Japanese media format could help unearth underlying complexities present in histories of media production, distribution, and aesthetics that have not yet been fully explored.

Drawing from the three examples highlighted in this paper, we might begin by recognizing that concepts of narrative film and documentary film in 1950s Japan differ from contemporary uses of the same terminology. The entangled histories of documentary film and magic lanterns contextualize postwar media in ways we might not expect. For example, what we might recognize today as independently produced narrative film often possessed cultural meanings close to those of documentary film. In a more direct relationship between the two forms, magic lantern films should be considered alongside documentary film in studies of postwar media history. The three cases observed in this paper demonstrate magic lanterns' distinct value to postwar media studies and their historical contexts.

Funding: This research was funded by Grants-in-Aid for Scientific Research, grant number 18K02022.

Acknowledgments: The titles of magic lantern films are based on the research by Hana Washitani. I would like to thank Eric Siercks for comments on a draft of this article.

Conflicts of Interest: The author declares no conflict of interest.

\section{References}

Anonymous. 1952. Genbaku no Zu. Soveto Eiga 3: 10. Also available in reprint: Soveto Eiga [Fukkokuban]. 5 vols. Tokyo: Fuji Shuppan.

Anonymous. 1954. Korede Sandome Bunshō no Suisen Tekkai: Kyōiku Eiga “Tsukinowa Kofun” ni. Asahi Shimbun. June 9. Available online: https://database.asahi.com/index.shtml (accessed on 15 May 2019).

Harada, Ken'ichi. 2012. CIE Eiga/Suraido no Nihonteki Juyō: "Niigata" toiu Jirei Kara. In Senryō suru Me, Senryō suru Koe: CIE/USIS Eiga to VOA Rajio. Edited by Yuka Tsuchiya and Yoshimi Shun'ya. Tokyo: Tokyo Daigaku Shuppankai.

Hyperallergic. 2015. Best of 2015: Our Top 10 Brooklyn Art Shows. Available online: https://hyperallergic.com/ 261439/best-of-2015-our-top-10-brooklyn-art-shows/ (accessed on 9 May 2019).

Jesty, Justin. 2018. Art and Engagement in Early Postwar Japan. Ithaca: Cornell University Press.

Kamiya, Makiko, and Hana Washitani. 2012. Post-war Social Movements Reflected through Gento. In Quest for Vision Vol. 5: Spelling Dystopia. Translated by Pamela Miki. Tokyo: Tokyo Metropolitan Museum of Photography.

Kanzaki, Kiyoshi. 1952. Yamabiko Gakkō. Eiga Hyōron 9: 5.

Kokuni, Yoshihiro. 2007. Sengo Kyōiku no nakano "Kokumin": Ranhansha suru Nashonarizumu. Tokyo: Yoshikawa Kōbunkan.

Okamura, Yukinobu. 2015. “Genbaku no Zu” Zenkoku Junkai: Senryōka 100 Man-nin ga Mita! Tokyo: Shinjuku Shobō. Okudaira, Yasuhiro. 1986. Eiga no Kokka Tōsei. In Sensō to Nihon Eiga: Kōza Nihon Eiga 4. Tokyo: Iwanami Shoten.

Sano, Shin'ichi. 2005. Tōi "Yamabiko": Muchaku Seikyō to Oshiego tachino 40 nen. Tokyo: Shinchōsha. First published 1992 
Toba, Koji. 2010. 1950 nendai: "Kiroku" no Jidai. Tokyo: Kawade Shobō Shinsha.

Toba, Koji. 2016. Sākuru-shi Nettowāku no Kanōsei: "Jinmin Bungaku" to “Shin-Nihon Bungaku" kara Miru Sengo Gariban Bunka. In "Sākuru no Jidai" o Yomu: Sengo Bunka Undō Kenkyū eno Shōtai. Edited by Unoda Shōya, Kawaguchi Takayuki, Sakaguchi Hiroshi, Toba Kōji, Nakaya Izumi and Michiba Chikanobu hen. Tokyo: Kage Shobō.

Tsuchiya, Yuka. 2009. Shinbei Nihon no Kōchiku: Amerika no Tainichi Jōhō, Kyōiku Seisaku to Nihon Senryō. Tokyo: Akashi Shoten.

Washitani, Hana. 2013. Sengo Rōdō Undō no Media to shiteno Gentō: Nikkō Muroran Sōgi ni okeru Un-yō o Chūshin ni. Engeki Kenkyu 36. Available online: http://hdl.handle.net/2065/40368 (accessed on 15 May 2019). Yoshihara, Junpei. 2011. Nihon Tanpen Eizōshi: Bunka Eiga, Kyōiku Eiga, Sangyō Eiga. Tokyo: Iwanami Shoten.

(C) 2019 by the author. Licensee MDPI, Basel, Switzerland. This article is an open access article distributed under the terms and conditions of the Creative Commons Attribution (CC BY) license (http://creativecommons.org/licenses/by/4.0/). 